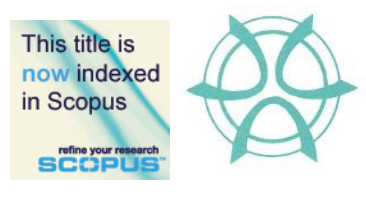

PLANNING MALAYSIA:

Journal of the Malaysian Institute of Planners

VOLUME 16 ISSUE 1 (2018), Page 130 - 143

\title{
AGEING IN PLACE FRAMEWORK AS REFERENCE GUIDE FOR HOUSING IN MALAYSIA: LANDED PROPERTY
}

\author{
Siti Uzairiah Mohd Tobi ${ }^{1}$, Mohamad Syazli Fathi ${ }^{2}$ \& Dilanthi \\ Amaratunga $^{3}$ \\ ${ }^{1,2}$ UTM Razak School of Engineering and Advanced Technology \\ UNIVERSITI TEKNOLOGI MALAYSIA, KUALA LUMPUR \\ ${ }^{3}$ School of Art, design and Architecture \\ UNIVERSITY OF HUDDERSFIELD, UNITED KINGDOM
}

\begin{abstract}
The increasing ageing population due to improved quality of life from better healthcare services and lifestyle as well as development in technology calls for better support in the ageing process. Even though the aged population dramatically increases globally, surprisingly the construction sector and the housing system seem slow in adapting to the changing needs of the ageing population. Increasing evidence show that population ageing is a pervasive and unparalleled global phenomenon which presents many challenges towards social and economic growth. Therefore, this research focuses on the provision of better support services and facilities of landed property, as well as the creation of sustainable environment that is age-friendly and safe. Data were collected using semi-structured interviews, focus group discussion and document reviews. Findings from cross sectional content analysis and cognitive mapping could enhance the standard of living for senior citizens in Malaysia in the context of ageing in place. A foundation for developing a comprehensive guideline for elderly, particularly in the urban areas, is proposed to improve the health and welfare of senior citizens in Malaysia through the provision of better services, facilities and development in landed properties.
\end{abstract}

Keyword: ageing in place, housing, facilities and services, social factors 
PLANNING MALAYSIA

Journal of the Malaysia Institute of Planners (2018)

\section{INTRODUCTION}

The ageing population is an effect from declining fertility rates as well longer life expectancy compared to previous decades (Lutz, Sanderson, \& Scherbov, 2008). This is due to improved quality of life from better healthcare services and lifestyle as well as development in technology that support the ageing process. Finally, the ageing of "baby boomers", which means the large number of children born after World War II in the United States and paralleled by similar booms in different places of the world have also lead to an increase in the number of seniors (Bloom, Boersch-Supan, McGee, \& Seike, 2011). Although it is deemed as a great achievement for mankind, population ageing also brings forward some of the greatest challenges faced by our current society due to its many consequences towards the economic, social and political wellbeing of nations.

Some of these challenges include a decline in economic growth due to a shrinking work force, issues in healthcare and pension systems, increase in dependency ratio, policy changes and a changing sector more focused towards the needs of the elderly (Bloom et al., 2011; Arshad \& Ahmad Bhat, 2013). Furthermore, the old age group is increasing due to a very low population growth and a growing average life span of 71.7 years for males and 75 years for females (Samad \& Mansor, 2013).

Consequently, there is a necessity to increase public awareness, construct the required infrastructure, and deliver various facilities along with accomplishment-oriented research in order to look after the aged population of Malaysia (Tey et al., 2016). Since the essentials of the aged population in Malaysia for housing strategies have not been well considered, this has caused major problems concerning the delivery of suitable shelters for the aged (Sulaiman, Baldry, \& Ruddock, 2006).

Ageing in place has been seen as one of the ways to address the issue of ageing population. Although there is a growing emphasis on ageing in place in more developed nations, there seems to be a shortage of current researches and publications on this topic in Malaysia, especially with regards to the built environment (Syed Abdul Rashid, Mohd Yusuff, Hamid, Goh, \& Hussain, 2006). Therefore, this study is significant as it contributes to the limited information regarding the current challenges faced by elderlies to age in place in Malaysia, particularly in urban area. This is in line with the efforts carried out by the government to improve the health and welfare of senior citizens in Malaysia through the provision of services, facilities, and suitable development (Syed Abdul Rashid et al., 2006). This research focuses on ageing in place in landed housing properties. It identifies the current challenges faced by elderly citizens in Malaysia, as well as it outlines the good practices for ageing in place. In the end, a framework is developed to serve as a reference in addressing ageing in place in Malaysia. 
Siti Uzairiah Mohd Tobi, Mohamad Syazli Fathi \& Dilanthi Amaratunga

Ageing in Place Framework as Reference Guide for Housing in Malaysia: Landed Property

\section{LITERATURE REVIEW}

\section{Definition of an Elderly Person}

Ageing can be defined as a biological, sociological, economic and chronological phenomenon (Karim, 1997). In this research, the chronological definition will be used, which is in line with the United Nations' and Ministry of Health's recommendations. Meanwhile, "the elderly or ageing population" means people aged 60 years or older. Although at the moment there is no United Nations standard numerical criterion, but the cut off age of 60 years refers to the elderly population has been adopted by many developing countries (Juni, 2015). Similarly, in Malaysia, elderly people are described as people aged 60 years and over (Ministry of Health, Labour and Welfare, 2013; Mohammad \& Abbas, 2012).

On the other hand, ageing can be described as an extensive concept which comprises mental capabilities and physical alterations, social characteristics, and psychological modifications to one's mind. Additionally, it takes into account the elderly person capability for his situation, self-care and position within family along with the social networks. These are related to their aptitude and capability to deliver on their behalf a suitable and pleasant life (Abdullah, Abdullah, \& AlMerbaw, 2013).

An ageing population is a domain that affects both developed and developing countries. Every month, one million people turn 60 . Furthermore, the projected growth of elderly group will increase exponentially, and the need for resources to care for older individuals will, therefore, rise proportionately. This growth will also result in an increased incidence of degenerative diseases and disabilities. This will lead to the needs of generating knowledge how to care for this population (Abdullah et al., 2013). Accordingly, as the number and percentage of older population continue to increase, the need for extensive and current information regarding elderly persons are becoming increasingly important to be discussed (Wan-Ibrahim \& Zainab, 2014).

\section{Elderly Physical Environment}

The importance of appropriate physical environment towards positively influencing the health and wellbeing of individuals, have been discussed by various authors (Netherlands Board for Healthcare Institutions, 2008; Lavin, Higgins, Metcalfe, \& Jordan, 2006; Joseph, 2006). There are various environmental hazards which could increase the susceptibility of elderly persons to injuries and falls, which include poorly designed stairs and handrails, bad lighting conditions, stepovers, uneven walkways and more (Wold, 2011; Kirby, 2004; Stevens, Holman, \& Bennett, 2001; Carter, Campbell, Sanson-Fisher, Redman, \& Gillespie, 1997). These risks are often made worse due to the weakened mental and physical states of the elderly individuals, as some live 
alone, and are isolated from friends and family in their homes. Thus, in order to make it safer for elderly persons to age in place, it is important to first create a safe physical environment for them to live in.

Todd and Skelton (2004) interpret the physical environment as a general definition which encompasses the home and community environment for an elderly person. This includes the housing options (own house, assisted living facility, nursing home and so on), public spaces (hospitals, supermarkets, parks and recreational spaces and more) and the spaces that connect these places together (public transport stations, pavements and walkways and so on). The National Council on Aging (2015) and Centre for Disease Control and Prevention (2016) report that one of the major risks from the physical environment for the elderly population is related to injuries from falls, which can result in lower selfesteem, reduced mobility, and serious injuries which require hospitalization. Furthermore, the barriers in the physical environment can cause mobility issues that will hamper active and healthy lifestyle habits and prevent access to much needed services and facilities within the community. Hence, it is important to develop physical environment that is suited for all community members regardless of their age and ability levels, as it will play a vital role in maintaining their quality of life.

Thus, the most recognized definition for the concept of ageing in place which has been extensively used in current studies is as follows:

“(Ageing in place is) the ability to live in one's own home and community safely, independently, and comfortably, regardless of age, income, or ability level". (Centre for Disease Control and Prevention, 2009).

\section{METHODOLOGY}

Accordingly, the research techniques used for main data collection process involved three approaches as follows:

\section{Semi-Structured Interviews (Stakeholder 1 - Local Government)}

The identified respondents were the Head of Departments who were involved with the welfare of elderly people and who were responsible to endorse the permission to renovate houses (landed property).

\section{Focus group discussion (Stakeholder 2 - Community Group)}

The identified respondents were the Residents Association Committee Members that comprised all three generations of family members; the parent - the children - the grandchildren. The justifications of ageing population are referred to the 'Generation X and Baby Boomers' age group type as below:

- The elderly (Baby Boomers - age group between 53-71 years old) 
Siti Uzairiah Mohd Tobi, Mohamad Syazli Fathi \& Dilanthi Amaratunga

Ageing in Place Framework as Reference Guide for Housing in Malaysia: Landed Property

- Ageing people (Generation X - age group between 37-54 years old).

Document Reviews

During the case study phase, document review was also used as a supplementary technique of data collection to triangulate the data collected. Relevant government documents on elderly policy and welfare were reviewed. However, this is not be discussed in this article.

\section{Data Analysis}

The cross-sectional analysis was done on the results from focus group discussion and interviews. The data gathered from both techniques would provide a better result since all data were now converged. The validity of the result was compared and discussed through the findings from all case studies with the evidence from the literature review findings. This process helped the researcher to scrutinise the transcripts towards finding the emerging patterns. These were later listed as free nodes before the related child nodes (sub nodes) were clustered to the main nodes (main themes). The final result of the analysis was then presented using cognitive mapping diagram that served to identify the initial framework model for ageing in place guideline. The content analysis was done using five general data analysis strategies, namely data display, code identification, information reduction, frequency of code, and category for relations data matrices and pattern matching.

NVivo11 was used to analyse the data. In summary, the analysis of the focus group discussion and interview transcripts shown in Figure 1 are examples of the 'content analysis' using those five data analysis strategies. The analysis of the content was done by filtering the transcript and to capture (code) only significant statements that represent the idea or information that literally derived from the early literature work done (deductively). The analysis was also done in agreement with the construct of new information (knowledge) that helps to expand towards new literature. Accordingly, the detail analysis method shown only for Theme 1 - Housing Related Areas as reference, before the summary of the overall findings are presented. Figure 1 shows a summary of the analysis done for Theme 1. 
PLANNING MALAYSIA

Journal of the Malaysia Institute of Planners (2018)

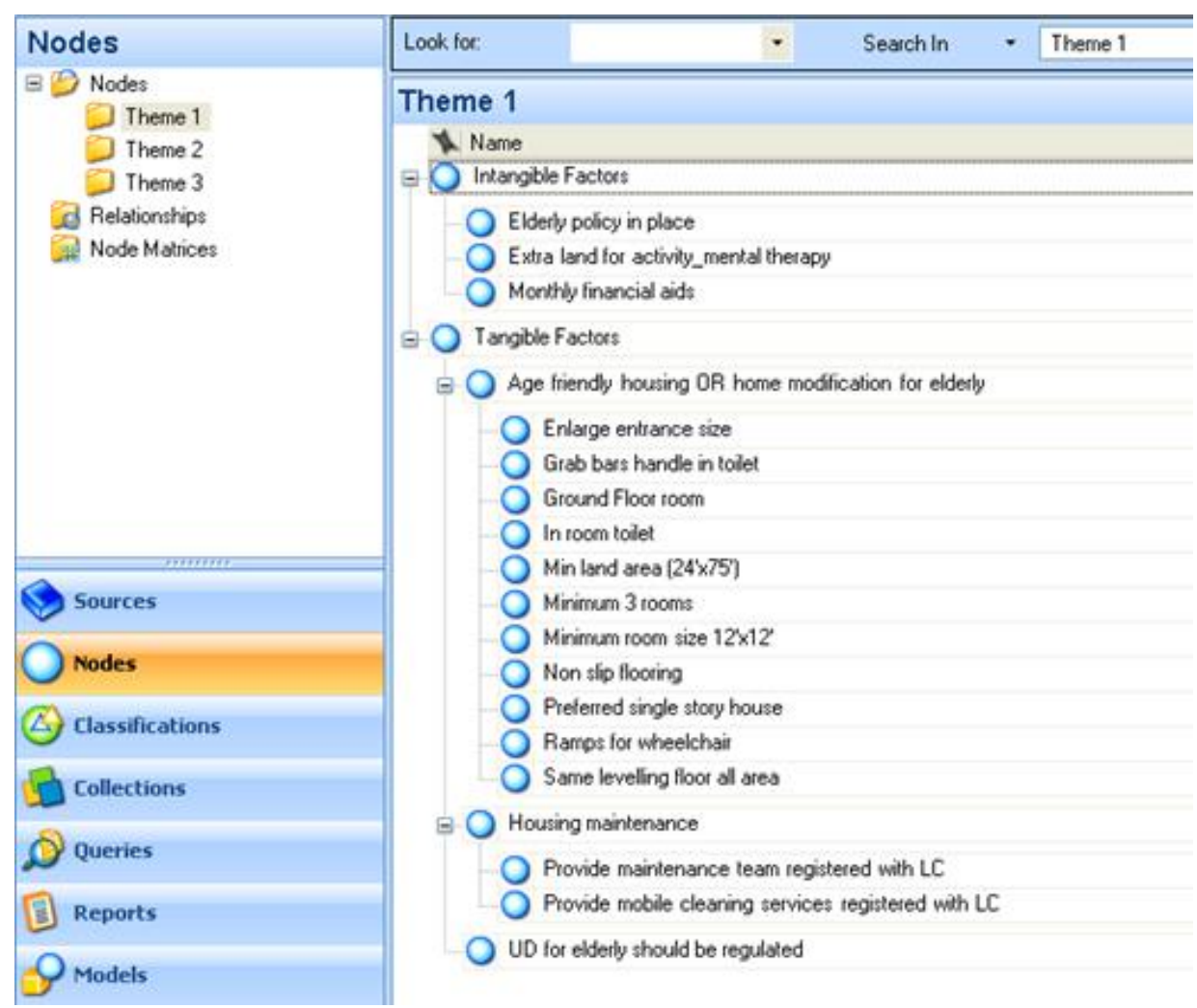

Figure 1: Summary of analysis done using NVivo11 - Theme 1

Figure 2 shows part of the analysing process for the cross-sectional content analysis for some of the factors under Theme 1 . 
Siti Uzairiah Mohd Tobi, Mohamad Syazli Fathi \& Dilanthi Amaratunga

Ageing in Place Framework as Reference Guide for Housing in Malaysia: Landed Property

\begin{tabular}{|c|c|c|c|}
\hline & \multicolumn{3}{|l|}{ Intangible Factors } \\
\hline & $\begin{array}{l}\text { Extra land for mental activity } \\
\text { therapy }\end{array}$ & Monthly financial aid & Elderly policy in place \\
\hline Case A & $\begin{array}{l}\text { Saya suka bercucultanam pagi- } \\
\text { pagi, jaga pokokfpokok bungd } \\
\text { saya }\end{array}$ & $\begin{array}{l}\text { Harapkan duit pencen mana } \\
\text { nak cukup, kena ada extra sikit } \\
\text { zaman sekarang ni }\end{array}$ & $\begin{array}{l}\text { Kita cakap-cakap, tapi } \\
\text { Kerajaan kena jadikan } \\
\text { arahan }\end{array}$ \\
\hline Case B & $\begin{array}{l}\text { Hobi saya ialah pertukang pada } \\
\text { barang-barang kayu, keja ada } \\
\text { area sikitlah, kecik pun/takpe }\end{array}$ & $\begin{array}{l}\text { Aanak-anak memang bagi/ } \\
\text { tapi tak tentu, pakcik pun } \\
\text { malas nak minta-mintd } \\
\text { macam BRIM tu cuba bagi } \\
\text { bulanan }\end{array}$ & $\begin{array}{l}\text { Semuanya } \\
\text { kepada } \\
\text { kerajaan }\end{array}$ \\
\hline Case C & $\begin{array}{l}\text { Tanam pokdk yong boleh buat } \\
\text { sayur, happy tengok menjadi } \\
\text { sayur yang kjla tanam tu }\end{array}$ & $\begin{array}{l}\text { Macam kat UK tu kan dia bagi } \\
\text { bantuan bulanan }\end{array}$ & $\begin{array}{l}\text { Pelaksanaan kena jelas } \\
\text { dari semua peringkat }\end{array}$ \\
\hline & $\begin{array}{l}\text { veloping 'codes' to develop the n } \\
\text { me and subthemes }\end{array}$ & $\begin{array}{l}\text { This process is } \\
\text { develop or assi }\end{array}$ & $\begin{array}{l}\text { called 'coding' in order to } \\
\text { gn a 'code' }\end{array}$ \\
\hline
\end{tabular}

Figure 2: Example of the content analysis process - Theme 1

\section{Cognitive Mapping using NVivo11}

As derived from the detail analysis process of the content analysis, the cognitive mapping was drawn. This was to show the summary of the analysis on the illustrated figures. Accordingly, the cognitive mapping developed were based on each themes identified from this study. 


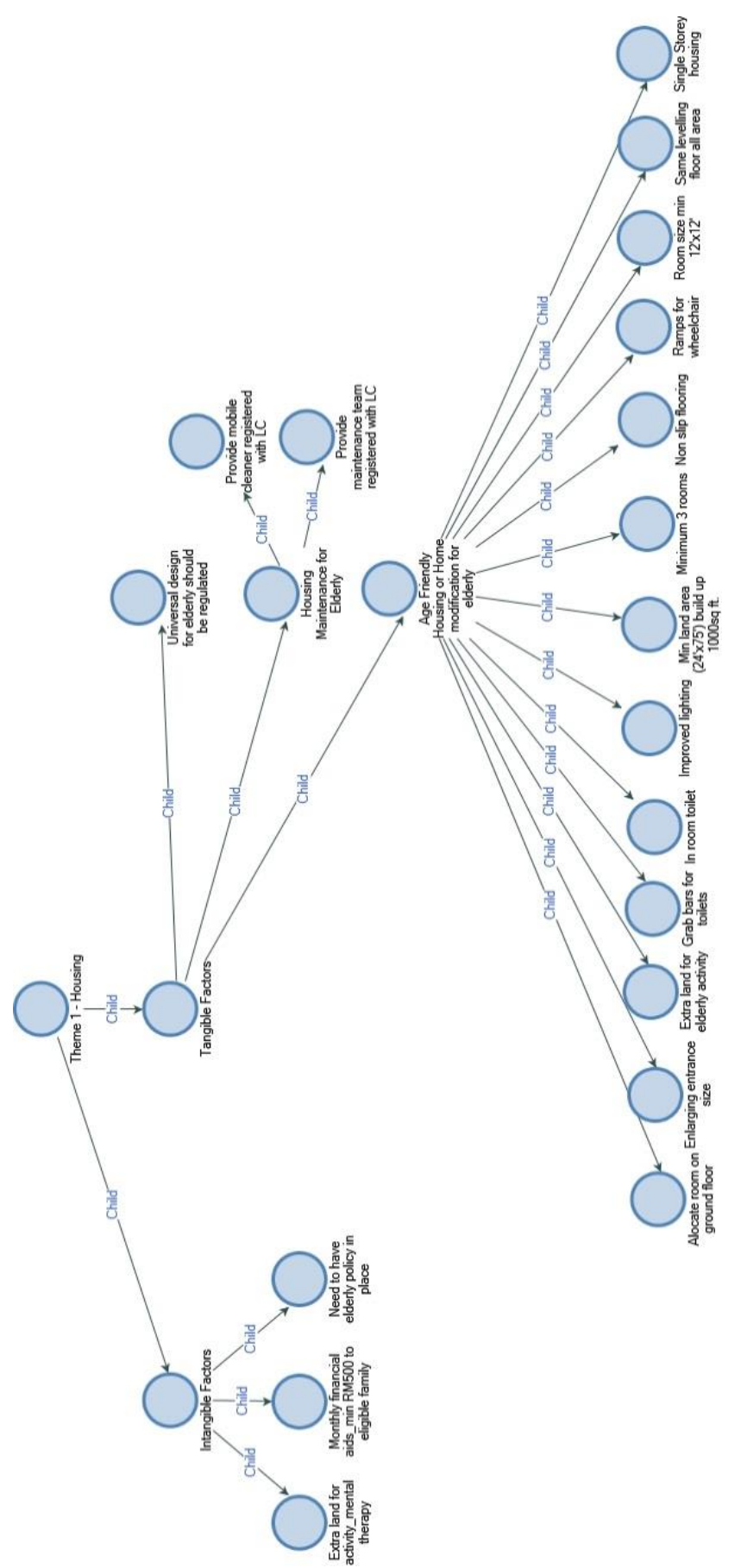

Figure 3: Cognitive mapping developed using NVivo - Theme 1 
Siti Uzairiah Mohd Tobi, Mohamad Syazli Fathi \& Dilanthi Amaratunga

Ageing in Place Framework as Reference Guide for Housing in Malaysia: Landed Property

\section{FINDINGS}

At the final stage of analysis, it was appropriate to summarize the results from the cross sectional content analysis from all cases. This process helped to accomplish both literal replication and theoretical replication and the results would stand more robustly. The summary of the results is presented in Table 1 to Table 3, grouped under the related themes.

Table 1: A matrix for generating summary of cross sectional content analysis (Theme 1) Theme 1 - Housing related area

\begin{tabular}{|c|c|c|}
\hline Intangible & \multicolumn{2}{|c|}{ Extra land for activity (mental therapy) } \\
\hline & \multicolumn{2}{|c|}{ Monthly financial aids (min RM500 to eligible families) } \\
\hline & \multicolumn{2}{|c|}{ The need to have an elderly policy in place } \\
\hline Tangible & \multirow{13}{*}{$\begin{array}{l}\text { Age friendly housing or } \\
\text { home modification for } \\
\text { elderly }\end{array}$} & Allocate rooms on ground floor \\
\hline \multirow[t]{15}{*}{ Factors } & & Enlarge entrance size \\
\hline & & Allocate extra land \\
\hline & & Grab bars for toilet \\
\hline & & Attached toilet \\
\hline & & Install Good lighting \\
\hline & & Minimum land area (24'x75') \\
\hline & & Minimum three rooms \\
\hline & & Minimum room size (12’x12') \\
\hline & & Non slip flooring \\
\hline & & Ramps for wheelchair \\
\hline & & Same levelling floor all area \\
\hline & & Single storey housing are preferred \\
\hline & \multirow[t]{2}{*}{$\begin{array}{l}\text { Housing } \\
\text { elderly }\end{array}$} & $\begin{array}{l}\text { Provide mobile cleaning services } \\
\text { registered with LC }\end{array}$ \\
\hline & & $\begin{array}{l}\text { Provide maintenance team registered } \\
\text { with LC }\end{array}$ \\
\hline & \multicolumn{2}{|c|}{ Universal Design (UD) for elderly should be regulated } \\
\hline
\end{tabular}

Table 2: A matrix for generating summary of cross sectional content analysis (Theme 2)

\begin{tabular}{lll}
\hline Theme 2 & Facilities and Services related areas \\
\hline Facilities & Activity Centre & $\begin{array}{l}\text { Need to have periodic or } \\
\text { scheduling activities }\end{array}$ \\
\cline { 2 - 3 } & Places of worship & Address different religion needs \\
Healthcare & Enough public ambulance is crucial \\
Services & Caregivers and caretakers support \\
& Health education and awareness program
\end{tabular}


PLANNING MALAYSIA

Journal of the Malaysia Institute of Planners (2018)

Mobile clinic and mobile Doctor

Nearest public clinic is essential

Visit or routine medical check-up from the nearest hospital

Transportation Increase the frequency of buses and local commuter trains

and mobility

Provide local transport to the community (for self-manage)

Smaller transport such as mini buses, vans, and cars

Various pick up points for public transport (that cover the inside area)

Table 3: A matrix for generating summary of cross sectional content analysis (Theme 3)

\begin{tabular}{|c|c|}
\hline \multirow[t]{3}{*}{ Community Safety and Security } & Crime protection and security \\
\hline & Periodic Police patrols \\
\hline & CCTV at strategic locations \\
\hline \multirow[t]{2}{*}{ Dissemination of information } & Encourage positive social interaction \\
\hline & Sharing of knowledge and expertise \\
\hline Financial Stability & Empowering the elderly for financial stability \\
\hline \multirow{2}{*}{$\begin{array}{l}\text { Government and other agencies fund } \\
\text { and support }\end{array}$} & Help under social welfare department \\
\hline & Senior citizen aid and funding \\
\hline \multicolumn{2}{|c|}{ Promote independence and self-empowerment } \\
\hline \multirow[t]{3}{*}{$\begin{array}{l}\text { Social Activities by Government, } \\
\text { NGOs, and private CSR }\end{array}$} & $\begin{array}{l}\text { As for now most activities are at mosque } \\
\text { (masjid) or musolla (surau) }\end{array}$ \\
\hline & $\begin{array}{l}\text { Community activities in group (involvement } \\
\text { from all) }\end{array}$ \\
\hline & $\begin{array}{l}\text { Government and NGOs need to conduct } \\
\text { activity that include (the elderly) }\end{array}$ \\
\hline \multicolumn{2}{|l|}{ Social support from local community } \\
\hline Stay close to family and relatives & \\
\hline
\end{tabular}

\section{RECOMMENDATIONS}

\section{The Proposed Framework for Ageing in Place Guideline}

The proposed framework to establish a guideline for ageing in place in Malaysia is derived from the results of the study and shown in Figure 4. 
Siti Uzairiah Mohd Tobi, Mohamad Syazli Fathi \& Dilanthi Amaratunga

Ageing in Place Framework as Reference Guide for Housing in Malaysia: Landed Property

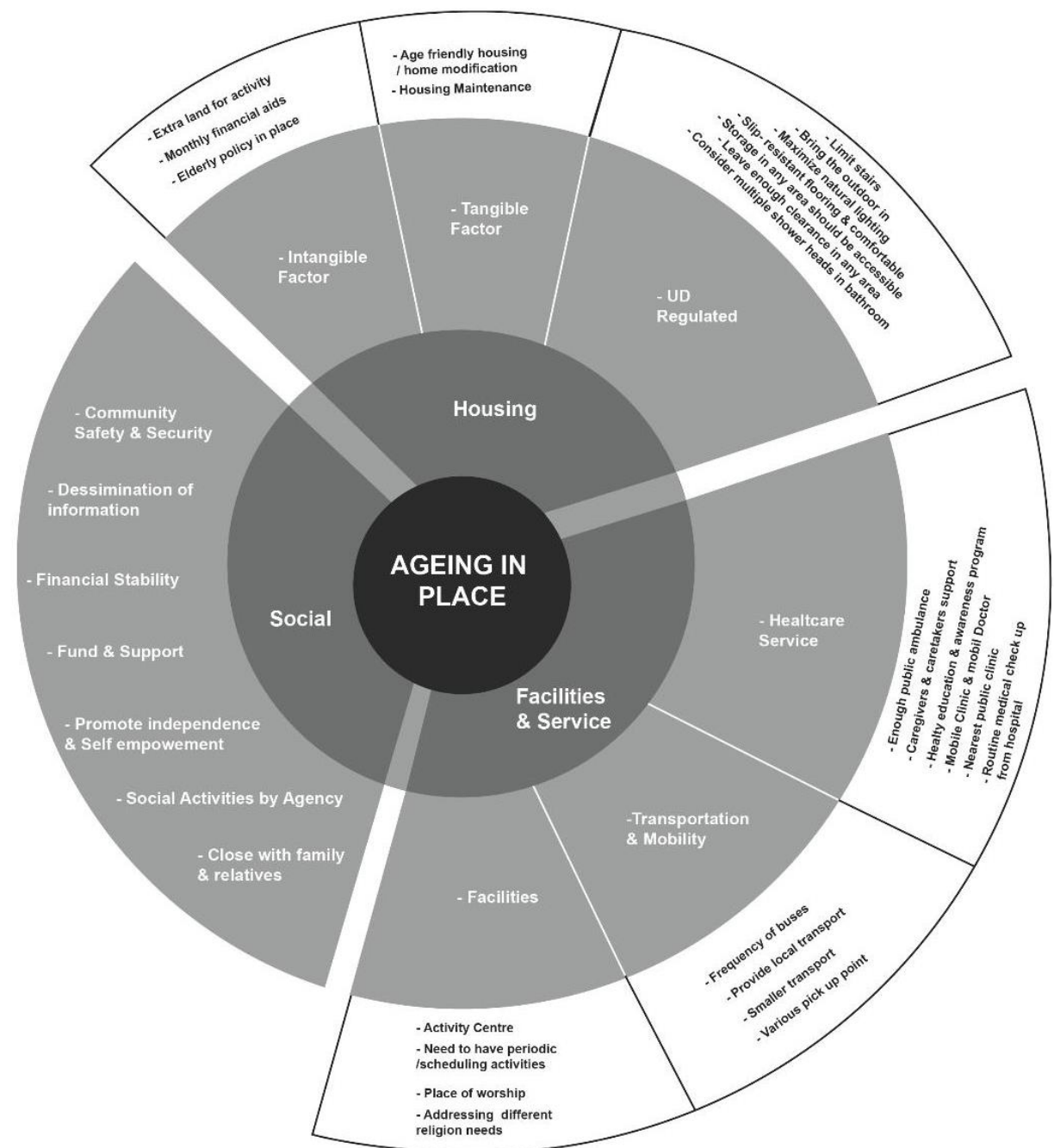

Figure 4: Framework for ageing in place guideline

The developed framework consists of the key themes and sub-themes that are related and complemented each other. Therefore, they should be used as a reference and consideration for both the policy maker and implementer before any development in relation with ageing community being undertaken. Having said this, the framework could be extended to other factors that contribute towards having a proper guideline for ageing in place in Malaysia so that the elderlies could live in age-friendly environment with age-friendly facilities and support. 
PLANNING MALAYSIA

Journal of the Malaysia Institute of Planners (2018)

\section{CONCLUSION}

This study has followed a rigorous research process by using multiple embedded case studies to gain an in-depth explanation through various measures, which have been done by using multiple data collection methods. However, there were limitations which were associated with limited stakeholders' involvement, towards seeking factors that contribute towards developing the proposed framework. The identified stakeholders came from two target groups, namely the community and representatives from local councils. Therefore, at this stage, the researchers were only seeking opinions and in depth understanding on the related area of focus in this study.

Further investigation needs to be done in order to improve and refine the findings before the final guideline can be developed. Future research can also examine other factors that can further refine the guidelines for ageing in place in Malaysia as shown in Table 4.

Table 4: Other related factors in developing the ageing in place guideline

\begin{tabular}{|c|c|}
\hline Other related factors & Description \\
\hline Technology & $\begin{array}{l}\text { Technology that relates with ageing in place topic, } \\
\text { would be the one that related to the mobility (high } \\
\text { tech wheelchair) for the elderly that not able to } \\
\text { walk anymore. } \\
\text { It is also related to high health tech devices to } \\
\text { monitor their health condition from remote. }\end{array}$ \\
\hline $\begin{array}{l}\text { Big Data and Internet of Thing } \\
\text { (IoT) }\end{array}$ & $\begin{array}{l}\text { The information from any devices will capture the } \\
\text { related data and info to be used for a particular } \\
\text { purpose or to improve the elderly conditions. }\end{array}$ \\
\hline Disabled people & Explore the particular needs of disabled people. \\
\hline $\begin{array}{l}\text { House design output based on } \\
\text { Universal Design (UD) principle }\end{array}$ & $\begin{array}{l}\text { Design drawing referred to the Universal Design } \\
\text { (UD) criteria, particularly for ageing in place }\end{array}$ \\
\hline
\end{tabular}

\section{ACKNOWLEDGEMENT}

The researchers thanks the funder of this research project, which is the Valuation and Property Services Department, Malaysia (INSPEN) under the NAPREC grant allocation. In addition, special thanks is also accorded to UTM Razak School of Engineering and Advanced Technology. 
Siti Uzairiah Mohd Tobi, Mohamad Syazli Fathi \& Dilanthi Amaratunga

Ageing in Place Framework as Reference Guide for Housing in Malaysia: Landed Property

\section{REFERENCES}

Abdullah, O. C., Abdullah, M. S. Y., \& Al-Merbaw, A. (2013). Ageing population in developed countries: A study of process and phenomena. Middle-East Journal of Scientific Research, 17(2), 219-225.

Arshad, M., \& Ahmad Bhat, S. (2013). Global ageing trends: A sociological perspective. International Journal of Current Research and Academic Review, 1(4), 55-64.

Bloom, D. E., Boersch-Supan, A., McGee, P., \& Seike, A. (2011). Population aging: Facts, challenges, and responses. PGDA Working Paper No. 71.

Carter, S. E., Campbell, E. M., Sanson-Fisher, R. W., Redman, S., \& Gillespie, W.J. (1997). Environmental hazards in the homes of older people. Journal of Age and Ageing, 26, 195-202.

Centre for Disease Control and Prevention. (2009). Healthy places terminology. National Center for Environmental Health.

Centre for Disease Control and Prevention (2016). Important facts about falls: Home and recreational safety. Retrieved 10 October 2016 from http://www.cdc.gov/homeandrecreationalsafety/falls/adultfalls.html

Joseph, A. (2006). The role of the physical and social environment in promoting health, safety, and effectiveness in the healthcare workplace. The Center for Health Design, Issue Paper 3 November 2006.

Juni, M. H. (2015). Ageing population: A public health implications. International Journal of Public Health and Clinical Sciences, 2(3).

Karim, H. (1997). The elderly in Malaysia: Demographic trends. Medical Journal of Malaysia, 52(3), 206-212.

Kirby, S. D. (2004). A housing safety checklist for older people. North Carolina Cooperative Extension Service.

Lavin, T., Higgins, C., Metcalfe, O., \& Jordan, A. (2006). Health impacts of the built environment: A review. Retrieved from https://www.publichealth.ie/publications/healthimpactsofthebuiltenvironmentarevi ew.

Lutz, W., Sanderson, W., \& Scherbov, S. (2008). The coming acceleration of global population ageing. Nature, 451, 716-719.

Ministry of Health, Labour and Welfare (2013). Country Report Malaysia. Retrieved October 3, 2016, from http://www.mhlw.go.jp/bunya/kokusaigyomu/asean/2013/dl/Malaysia_CountryRe port.pdf.

Mohammad, N. M. N., \& Abbas, M. Y. (2012). Elderly environment in Malaysia: Impact of multiple built environment characteristics. Procedia - Social and Behavioral Sciences, 49, 120-126.

National Council on Aging (2015). There's no place like home - for growing old. U.S. Department of Health and Human Services.

Netherlands Board for Healthcare Institutions. (2008). Quality of the physical health care environment. Status of research on environmental variables and the effects on (sick) people (Report number 617).

Samad, S. A., \& Mansor, N. (2013). Population ageing and social protection in Malaysia. Malaysian Journal of Economic Studies, 50(2), 139-156. 
Stevens, M., Holman, C.D., \& Bennett, N. (2001). Preventing falls in older people: Impact of an intervention to reduce environmental hazards in the home. Journal of the American Geriatrics Society, 49(11), 1442-1447.

Sulaiman, N., Baldry, D., \& Ruddock, L. (2006, April). Issues concerning housing for the elderly in Malaysia. 6th International Postgraduate Research Conference, April 67, 2006, Delft University of Technology, the Netherlands.

Syed Abdul Rashid, S. N., Mohd Yusuff, R., Hamid, T. A., Goh, S. C., \& Hussain, M. R. (2006). Ageing-in-place: Towards an ergonomically designed home environment for older Malaysians. Gerontechnology, 5(2), 92-98.

Tey, N. P., Siraj, S. B., Kamaruzzaman, S. B. B., Chin, A. V., Tan, M. P., Sinnappan, G. S., \& Muller, A. M. (2016). Aging in multi-ethnic Malaysia. Gerontologist, 56(4), 603-609.

Todd, C., \& Skelton, D. (2004). What are the main risk factors for falls among older people and what are the most effective interventions to prevent these falls? Health evidence network report. Copenhagen, WHO Regional Office for Europe.

Wan-Ibrahim, W., \& Zainab, I. (2014). Some demographic aspects of population aging in Malaysia. World Applied Sciences Journal, 30(7), 891-894.

Wold, G. H. (2012). Evolve resources for basic geriatric nursing (5th Edition). St. Louis, Missouri: Elsevier Mosby 